\author{
Konrad Klejsa \\ (University of Lodz, Poland) \\ https://orcid.org/0000-0002-6259-9173 \\ E-mail: konrad.klejsa@uni.lodz.pl
}

\title{
Armia Krajowa w niemieckim serialu - ćwiczenie z teorii i interpretacji
}

The Home Army in German TV Series. An Exercise in Theory and Interpretation

ABSTRACT

The article deals with the representation of World War II in the German Generation War and focuses on one particular plot, connected with the character of a German Jew who joins a Home Army unit. The way these events had been depicted, led to a lawsuit filed by a Home Army veteran and the Home Army World Alliance against the producers of the series. The main subject of the analysis are two main, extensive court letters (the lawsuit and the answer to it). They refer to both general issues (concerning the classification of historical films) and specific ones, namely five particular scenes from the film. On this basis, the author builds an argument, in the first part broadening the spectrum of theoretical reflection, and in the latter part concentrating on the interpretation of controversial scenes from the series. The analysis leads to the conclusion that the stylistic pattern applied by the creators and the multitude of textual elements used in the series is particularly important for the consideration of the objections raised by the complainant and during the trial.

\begin{tabular}{|c|c|c|c|c|}
\hline \multicolumn{5}{|c|}{ PUBLICATION INFO } \\
\hline IH & UMCS & 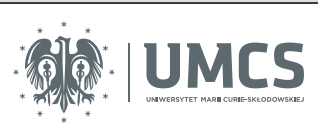 & $\begin{array}{l}\text { e-ISSN: } 2449-8467 \\
\text { ISSN: } 2082-6060\end{array}$ & OPEN@ACCESS \\
\hline \multicolumn{5}{|c|}{$\begin{array}{l}\text { THE AUTHOR'S ADDRESS: Konrad Klejsa, the Institute of Contemporary Culture of the University of Lodz, } \\
\text { 171/173 Pomorska Street, tódź 90-236, Poland }\end{array}$} \\
\hline \multicolumn{5}{|c|}{ SOURCE OF FUNDING: Statutory Research of the Institute of Contemporary Culture of the University of Lodz } \\
\hline $\begin{array}{l}\text { SUBMITTED: } \\
\text { 2018.12.05 }\end{array}$ & & $\begin{array}{l}\text { ACCEPTED: } \\
2020.01 .15\end{array}$ & $\begin{array}{l}\text { PUBLISHED ONLINE: } \\
\text { 2021.06.30 }\end{array}$ & (c) \\
\hline \multicolumn{3}{|c|}{$\begin{array}{l}\text { WEBSITE OF THE JOURNAL: } \\
\text { https://journals.umcs.pl/rh }\end{array}$} & $\begin{array}{l}\text { EDITORIAL } \\
\text { COMMITTEE E-mail: } \\
\text { reshistorica@umcs.pl }\end{array}$ & 8 Crossref dol \\
\hline
\end{tabular}



rights

Key words: history in film, Home Army, ZDF television, infringement of personal

\section{STRESZCZENIE}

Artykuł dotyczy sposobu reprezentacji II wojny światowej w niemieckim miniserialu Nasze matki, nasi ojcowie. Autor skupia się na jednym wątku, związanym z postacią niemieckiego Żyda, który trafia do oddziału Armii Krajowej. Kanwą rozważań jest pozew sądowy wystosowany przez kombatanta AK oraz Światowy Związek Armii Krajowej przeciw producentom serialu. Zasadniczym przedmiotem analizy są dwa główne, obszerne pisma sądowe (pozew oraz odpowiedź nań). Odnoszą się one zarówno do zagadnień ogólnych - dotyczących klasyfikacji filmów historycznych, jak i szczegółowych - pięciu konkretnych scen z filmu. Na tej podstawie autor buduje wywód w pierwszej części poszerzający spektrum refleksji teoretycznej, w drugiej zaś - koncentrujący się na interpretacji kontrowersyjnych scen z serialu. Analiza prowadzi do wniosku, że mnogość zastosowanych $\mathrm{w}$ serialu elementów jest szczególnie istotna dla rozpatrzenia zastrzeżeń wnoszonych przez stronę skarżącą.

Słowa kluczowe: historia w filmie, Armia Krajowa, telewizja ZDF, naruszenie dóbr osobistych

Prawdopodobnie najczęściej w Polsce komentowaną niemiecką produkcją filmową ostatniego dziesięciolecia był trzyodcinkowy miniserial Nasze matki, nasi ojcowie (reż. Philipp Kadelbach, Niemcy 2013). W kategoriach ekonomicznych była to superprodukcja (kosztowała ok. 14 milionów euro, z czego telewizja ZDF przekazała ok. 10 milionów), która osiągnęła ponadprzeciętnie dobrą oglądalność. Gdy w Niemczech serial wyemitowano po raz pierwszy w marcu 2013 r., każdy z odcinków przyciągnął przed ekrany od 6,5 do 7,5 miliona widzów, co stanowiło od 20 do 25 procent całej widowni (gospodarstw domowych mających włączone odbiorniki telewizyjne $)^{1}$. Recenzje były mieszane; najogólniej mówiąc, z jednej strony podkreślano kunszt realizatorski, z drugiej zaś zwracano uwagę, że serial wpisuje się w cykl tzw. Opfernarrativen - narracji o Niemcach jako ofiarach II wojny światowej. Głos w sprawie serialu zabrała także Ambasada RP w Berlinie oraz dyrektor TVP; ten ostatni zdecydował również o emisji serialu w czerwcu 2013 r. Wywołał on niezwykle emocjonalną reakcję - fora internetowe rozgrzały się do czerwoności, a wśród zarzutów wobec serialu często powtarzano relatywizację niemieckich zbrodni i przypisywanie jej Polakom².

1 M. Weis, Nico Hofmanns Weltkriegsfilm verfehlt den Tagessieg, http://www.quotenmeter. de/n/62693 [dostęp: 20 X 2018].

2 Niniejszy artykuł nie dotyczy recepcji serialu, choć niewątpliwie zasługuje ona na wnikliwą analizę. Próbę taką podjęły: M. Saryusz-Wolska, C. Piorun, Verpasste Debatte. "Unsere Mütter, unsere Väter" in Deutschland und Polens, "Osteuropa” 2014, 64, 11/12, s. $115-132$. 
Akcja serialu rozgrywa się podczas II wojny światowej - począwszy od 1941 r. - i opowiada o losach piątki młodych przyjaciół: trójki mężczyzn i dwóch kobiet. Wilhelm jest oficerem Wehrmachtu, który wyrusza ze swoim młodszym bratem Friedhelmem na front wschodni. Charlotte zgłasza się do służby medycznej, zaś jej przyjaciółka Greta zostaje piosenkarką i wikła się w romans z gestapowcem, dzięki któremu ma nadzieję ocalić swego ukochanego, Viktora. Ten zaś jest niemieckim Żydem, który ucieka z transportu do obozu i dołącza do partyzantów z Armii Krajowej. Właśnie ten wątek - z ok. 270 minut czasu ekranowego (każdy odcinek trwa około półtorej godziny) sceny rozgrywające się na terenach znakowanych jako „Polen” zajmują łącznie ok. 40 minut (z czego ponad połowę - w odcinku III) - szczególnie zbulwersowały wielu polskich widzów.

Pięć miesięcy po polskiej emisji serialu, w Sądzie Okręgowym w Krakowie został złożony pozew przeciw koproducentom serialu (UFA Fiction Gmbh z siedzibą w Poczdamie oraz telewizji ZDF z siedzibą w Moguncji) o naruszenie dóbr osobistych oraz prawa do znaku (AK) ${ }^{3}$. Strona skarżąca - Zbigniew Radłowski oraz Światowy Związek Armii Krajowej - wnosiła m.in. o (1) zobowiązanie pozwanych do umieszczenia we wszystkich kanałach dystrybucji serialu przeprosin „za naruszenie dóbr osobistych poprzez prezentowanie nieprawdziwych informacji i zdarzeń, które mogły sugerować, że żołnierze Armii Krajowej byli współwinni Holocaustu, dopuszczali się mordów na osobach narodowości żydowskiej oraz reprezentowali postawy antysemickie", (2) zaprzestanie pokazywania w serialu znaku Światowego Związku Żołnierzy Armii Krajowej (opaska z grafiką - skrótem AK); (3) zasądzenie zadośćuczynienia finansowego na rzecz powodów, a także o przesłuchanie biegłych z zakresu kinematografii, historii i psychologii społecznej.

Przeważająca część pisma powoda zawiera opis faktów notoryjnych (powszechnie znanych) dotyczących działalności Armii Krajowej (tekst przysięgi Armii Krajowej, dokumentacja z Muzeum Auschwitz-Birkenau oraz Instytutu Yad Vashem) oraz faktów związanych z powodami (biografia kpt. Radłowskiego, statut Stowarzyszenia Światowego Związku

3 „Pozew o naruszenie dóbr osobistych, prawa do znaku, wraz z żądaniem złożenia przeprosin i zadośćuczynienia" z 18 listopada 2013 r. [dalej: Pozew], złożony za pośrednictwem reprezentującej powoda warszawskiej Kancelarii Pasieka, Derlikowski i Partnerzy w Sądzie Okręgowym w Krakowie, Wydział I Cywilny (sygn. akt. I C 2007/13 - pod tą sygnaturą są też wszelkie inne dokumenty związane z procesem). Kilka tygodni później pozew został uzupełniony o „sprecyzowanie żądania”, w którym strona reprezentująca powoda domaga się od pozwanych przedstawienia pełnej listy kanałów dystrybucji („Sprecyzowanie żądania” z 27 grudnia 2013 r.). Na początku następnego roku do sądu wpłynęło kolejne „doprecyzowanie powództwa”; zawarto w nim treść anglojęzycznej wersji przeprosin („Doprecyzowanie powództwa” z 28 lutego 2014 r.). 
Żołnierzy AK), a także opis stanu prawnego dotyczącego ochrony dóbr osobistych, dobrego imienia oraz symboli osób prawnych. Uwagi odnoszące się do samego filmu (jego konkretnych scen) zajmują niespełna 30 procent właściwej części pozwu ${ }^{4}$, do którego dołączono także niemal 120 stron załączników o charakterze kontekstowym (wśród nich - kopie licznych stron internetowych dokumentujące recepcję serialu w Polsce, a także materiały dotyczące Stanisława Aronsona ${ }^{5}$ ). Zdaniem powodów, naruszenie ich dóbr osobistych nastąpiło poprzez:

Pokazanie, że Armia Krajowa jest współwinna zbrodni na narodzie żydowskim - w filmie przedstawiono żołnierzy Armii Krajowej jako skrajnych antysemitów [...].

Pokazanie Armii Krajowej jako organizacji bandyckiej, skarykaturyzowanej poprzez ukazanie postaci pseudo-żołnierzy - cywilnej bandy [...]. Wszyscy członkowie tego oddziału zieją nienawiścią do Żydów. Biorąc pod uwagę ich zachowanie, są oni po prostu grupą bandytów, zamaskowanych częściowo mundurami i noszonymi przez wszystkich partyzantów w filmie biało-czerwonych opasek z dużymi literami AK - jest to jakby podpis dla widza, co to za rodzaj bandytów (noszenie w taki sposób opasek w rzeczywistości historycznej nie miało miejsca, za wyjątkiem okresu Powstania Warszawskiego) 6 .

Odpowiedź na pozew, sformułowana przez reprezentujących pozwanych mecenas Karolinę Góralską oraz mecenasa Piotra Niezgódkę, nadeszła po ponad roku, w piśmie procesowym z 27 lutego 2015 r. ${ }^{7}$ Do liczącej 39 stron głównej części pisma dołączono również ponad 100 stron załączników, wśród których wyróżnić można trzy grupy: (1) ekspertyzy historyczne dotyczące nie filmu, a samej Armii Krajowej; ; (2) informacje dot. serialu - m.in. tabelaryczne zestawienie nagród przyznanych tej produkcji

\footnotetext{
4 Pozew, s. 4, 18-20, 22-26.

5 Stanisław Aronson - polski Żyd, oficer Armii Krajowej w stopniu podporucznika, uczestnik Powstania Warszawskiego, po wojnie podpułkownik Sił Obronnych Izraela.

6 Pozew, s. 18.

7 „Odpowiedź na pozew”, przygotowana przez Kancelarię Góralski i Góralska z 27 lutego 2015 r. [dalej: Odpowiedź].

8 Były to trzy opracowania: A. Skibińska, "Dostał 10 lat, ale za co?”. Analiza motywacji sprawców zbrodni na Żydach na wsi kieleckiej w latach 1942-1944, w: Zarys krajobrazu. Wieś polska wobec zagłady Żydów 1942-1945, red. B. Engelking, J. Grabowski, Warszawa 2011, s. 313-444; J. Mazurek, A. Skibińska, "Barwy Biate” w drodze na pomoc walczacej Warszawie. Zbrodnie AK na Żydach, "Zagłada Żydów. Studia i Materiały” 2001, 7, s. 422-465; A. Bikont, "Nie trzeba było domu palić, tylko Żydów wyprowadzić i pozabijać". Postscriptum do tekstu Jerzego Mazurka i Aliny Skibińskiej "Barwy Białe” w drodze na pomoc walczacej Warszawie: zbrodnie AK na Żydach, „Zagłada Żydów. Studia i Materiały” 2001, 7, s. 466-469.
} 
oraz broszurę reklamową wyprodukowana przez ZDF; (3) informacje dotyczące polityki programowej telewizji ZDF - tabelaryczne zestawienie filmów wyemitowanych przez pozwanego od 2013 r. związanych z tematyką II wojny światowej oraz dwie płyty DVD z filmami dokumentalnymi wyprodukowanymi przez ZDF. Przedstawiciele pozwanych wnosili o oddalenie powództwa w całości, w tym: o oddalenie wniosków skarżących o dopuszczenie dowodów biegłych. Sąd nie przychylił się do wniosku przedstawicieli pozwanych i podjął czynności procesowe (powołanie na biegłego z zakresu kinematografii otrzymał autor tej pracy).

W niniejszym artykule wykorzystuję główne tezy z ekspertyzy przygotowanej na zlecenie Sądu Okręgowego w Krakowie (zeznania złożyłem na rozprawie $\mathrm{w}$ dniu 17 stycznia 2018 r.), odnoszę się także do obu wzmiankowanych pism (tj. pozwu z listopada $2013 \mathrm{r}$. oraz odpowiedzi na pozew z lutego 2015 r.). Decyzja taka oznacza, że nie zostaną przytoczone zeznania przesłuchiwanych świadków ani późniejsze akta sprawy. Przedmiotem analizy nie są też zagadnienia ściśle prawne; oba przywoływane pisma procesowe służą jedynie jako pretekst do rozważań z zakresu teorii filmu oraz metod historiografii. Frazy zawarte w powództwie oraz odpowiedzi (mianowicie: „w filmie przedstawiono” oraz „w rzeczywistości historycznej") wyznaczają bowiem nie tylko główne osie sporu, ale też, w szerszym ujęciu, bieguny teoretycznej refleksji nad filmami podejmującymi wątki historyczne. Z jednej bowiem strony (i tego aspektu dotyczyć będzie niniejszy artykuł) przedmiotem namysłu jest przedstawienie (wyglądy oraz wydarzenia fabularne) będące wytworem działań artystycznych; z drugiej zaś - uruchamiany jest swoisty "tryb komparatystyczny", ukierunkowany na porównywanie tego, co pokazano na ekranie, i tego, co faktycznie wydarzyło (lub: wydarzało) się w okresie historycznym, którego dotyczy dany film (świadczą o tym w szczególności załączniki do pism procesowych - informacje o Aronsonie oraz ustalenia badaczy z Centrum Badań nad Zagładą Żydów przy Polskiej Akademii Nauk).

\section{AKTORSKI FILM FABULARNY JAKO SPOSÓB NARRACJI HISTORYCZNEJ}

Zaskakująco wiele miejsca w obu pismach procesowych zajmują uwagi dotyczące przynależności gatunkowej serialu. W pozwie pojawia się następujące stwierdzenie: „serial Nasze matki, nasi ojcowie musi podlegać surowszym rygorom oceny filmu nie tylko pod kątem prawdopodobieństwa występujących w nim zdarzeń, ale także ich reprezentatywności dla określonej rzeczywistości historycznej. Jest to rozstrzygnięcie o niezwykle istotnym metodologicznie znaczeniu, gdyż w zwykłych przypadkach oceny jakości filmu to drugie kryterium nie dotyczy utworów fabularnych, 
a jedynie dokumentalnych" ${ }^{\prime 9}$. Argumentację tę przedstawiciele pozwanych próbują odeprzeć następującym wywodem:

Film fabularny to film posiadający fabułę, czyli spójną opowieść losach [pisownia org.] jego bohaterów, z reguły postaci fikcyjnych. Co nie przeszkadza, że historia bohaterów może być pokazana na tle rzeczywistych wydarzeń. Rzeczywistość przedstawiona w filmie fabularnym jest fikcją jest kreacją jego twórcy. Film fabularny poza tym, że opowiada historię to odzwierciadla wizję rzeczywistości twórcy, która przełożona jest przez scenarzystę i reżysera. Kinematografia służy rozrywce, jednak tak jak każda forma wyrazu artystycznego także film fabularny może stawiać ważne pytania, rozprawiać się z problemami społecznymi, politycznymi. Poruszać, skłaniać do refleksji. W przeciwieństwie do tego film dokumentalny jest zapisem rzeczywistości ${ }^{10}$.

Ponieważ tego rodzaju sformułowania, charakterystyczne dla potocznego myślenia o kulturze filmowej, pojawiają się niekiedy w opracowaniach dydaktycznych, warto poświęcić nieco miejsca pogłębionej refleksji na temat problemów genologicznych ewokowanych przez filmy o tematyce historycznej. Otóż w nomenklaturze polskiej, anglojęzycznej i niemieckiej mamy do czynienia z różnymi określeniami podobnych fenomenów - rozpowszechniona w Polsce nomenklatura (film fabularny) ma charakter głównie znakujący (np. wykorzystywany do celów reklamowych czy informacyjnych - np. anons "film fabularny" w programie telewizyjnym) i jest mniej precyzyjna niż niemiecka (Spielfilm - film aktorski, czyli „zagrany") czy angielska (fiction film). Badacze zdają sobie sprawę z tej fundamentalnej różnicy - i słabości polskiego uzusu językowego; stąd coraz częściej - także na wykładach uniwersyteckich - wprowadza się w miejsce pojęcia "film fabularny" bardziej precyzyjny termin: film fikcjonalny (o relacjach tegoż z filmem historycznym będzie jeszcze mowa).

W słowniku Marka Hendrykowskiego czytamy wprost: „fabularny film: 1. synonim filmu fikcji, 2. przeciwieństwo filmu niefabularnego"11. Innymi słowy, antonimem tego, co $\mathrm{w}$ języku polskim określa się jako „film fabularny”, nie jest film dokumentalny - bowiem, jak zauważa Mirosław Przylipiak, czołowy badacz dokumentalistyki, fabuła występuje także w pokaźnej części dokumentów ${ }^{12}$. Inaczej mówiąc, „przekaz fikcjonalny może istnieć również poza strukturą fabularną a struktura

\footnotetext{
9 Pozew, s. 32.

10 Odpowiedź, s. 5.

11 M. Hendrykowski, Słownik terminów filmowych, Poznań 1994.

12 M. Przylipiak, Poetyka filmu dokumentalnego, Gdańsk-Słupsk 2004, s. 77.
} 
fabularna może organizować inne prócz fikcjonalnych rodzaje przekazów"13. Obserwacja ta jest szczególnie istotna w odniesieniu do współczesnej kultury audiowizualnej, w której coraz trudniej określić rodzajową specyfikę komunikatu filmowego - istnieją bowiem, i wcale nie należą do rzadkości, dokumenty zawierające partie zainscenizowane lub filmy fikcjonalne udające dokumenty ${ }^{14}$. Nie ulega natomiast wątpliwości, że istnieje kategoria filmów fabularnych, w których stopień fikcjonalizacji jest bardzo wysoki (byłyby to filmy z kręgu fantastyki - gatunki takie jak science-fiction, horror, fantasy czy baśń). Filmy określane jako historyczne muszą siłą rzeczy (można powiedzieć: ze swej natury) posługiwać się mniejszym stopniem fikcjonalizacji.

Dobrym przykładem nieporozumień dotyczących kwestii rodzajowo-gatunkowych są zawarte w pismach reprezentantów strony pozwanej niektóre określenia, które mogą być traktowane jedynie jako ślady myślenia potocznego. W szczególności chodzi o następujące passusy z pisma z 27 lutego 2015: „wymóg przedstawiania rzeczywistości w sposób przyjęty $\mathrm{w}$ odniesieniu do filmów dokumentalnych zakłada przedstawienie wszystkich, a nie tylko wybranych, faktów historycznych"15 (komentarz KK: spełnienie takiego wymogu przez jakikolwiek film byłoby niemożliwe); „W przypadku utworów inspirowanych autentycznymi wydarzeniami swoboda artystyczna pozwala twórcom danego obrazu dokonać selekcji określonych, pożądanych dla dramaturgii wydarzeń, z pominięciem innych"16 (dokładnie to samo można powiedzieć o filmach dokumentalnych); „,w filmie dokumentalnym obraz oddaje rzeczywistość taką jaka jest"17 (autorzy tego przemyślenia mylą najwyraźniej film dokumentalny z monitoringiem).

W świetle powyższych uwag teoretycznych warto przywołać artykuł pod znamiennym tytułem Film historyczny jako "gatunek dwojakiego

13 Ibidem, s. 79.

14 Chodzi w szczególności o tzw. mockumenty - zob. B. Kosińska-Krippner, Parodystyczna natura przywłaszczania kodów i konwencji faktualnych w mock-dokumentach, „Kwartalnik Filmowy" 2006, 56, s. 47-72; A. Ogonowska, «Mock-documentary» $i$ «faction genre»: wyzwanie dla kina dokumentalnego i paratekstualne gry z widzem, w: Kino po kinie. Film w kulturze uczestnictwa, red. A. Gwóźdź, Warszawa 2010, s. 269-292.

15 Odpowiedź, s. 22.

16 Ibidem.

17 Ibidem, s. 5. W tym kontekście warto raz jeszcze przytoczyć jeszcze jedną uwagę Przylipiaka: „obiektywizm nie jest wcale synonimem przekazów niefikcjonalnych ani ich wyróżnikiem. Przekazy takie mogą się bardzo mocno angażować w pewną ideologię, w pewną wersję rzeczywistości albo w określony wariant wydarzeń. Mogą więc być stronnicze i tendencyjne, mogą też, rzecz jasna, kłamać". M. Przylipiak, op. cit., s. 65. 
rodzaju"18. Piotr Witek zwraca w nim uwagę, że film historyczny jest de facto formą odmienną od tradycyjnie pojmowanego filmu fabularnego i zarazem odmienną od tradycyjnie pojmowanego filmu dokumentalnego. W innym miejscu ten sam autor pisze: „od filmu historycznego żąda się jedynie, albo aż, aby nie fałszował oficjalnej, naukowej wersji historii [...] ocena filmu jako dzieła historycznego powinna przebiegać nie na płaszczyźnie wypracowanych w obrębie historiografii szczegółów, ale na poziomie efektów strategii argumentacji, metaforyzacji i symbolizacji, a więc form audiowizualnego modelowania historycznego świata możliwego oraz tego, w jaki sposób film pozwala rozumieć przeszłość"19.

We współczesnym piśmiennictwie przyjmuje się, że praca twórcy filmowego (zajmującego się filmem historycznym) oraz historyka jest zbliżona - ma charakter konstrukcyjny („,czyż mając możliwość korzystania z tych samych źródeł wszyscy historycy napisaliby taką samą historię Rewolucji?" 20 - pyta retorycznie Marc Ferro). Film historyczny (zarówno aktorski, jak i dokument) tworzy zawsze zredukowane i częściowe przedstawienie spektrum zdarzeń, do których się odnosi; w każdym wypadku mamy do czynienia z subiektywizacją ekranowych przedstawień; dociera do nas jedna z wielu potencjalnych perspektyw. Nie jest to jednak specyfika wyłącznie filmowego medium, lecz także tradycyjnej historiografii, która również posługuje się wzorami narracyjnymi i figurami retorycznymi, wywodzącymi się ze sztuk fabularnych. Już kilka dekad temu podkreślał to m.in. Hayden White, który na zastrzeżenia wywoływane przez filmowe uogólnienia czy skróty odpowiadał, iż prawdziwość filmowej sekwencji „powinna zostać ulokowana nie na poziomie konkretu, lecz na innym poziomie właściwym typizacji. Sekwencję tę należy uważać za reprezentacje jakiegoś typu wydarzenia. Tym, do czego odsyła, jest typ wydarzenia ukazanego na ekranie" ${ }^{21}$. W kontekście serialu, o którym mowa $\mathrm{w}$ niniejszym artykule, trzeba powiedzieć, że jest to stanowisko zbliżone

18 P. Witek, Film historyczny jako "gatunek dwojakiego rodzaju”. Kilka uwag metodologicznych o "(nie)użyteczności” teorii genologicznej w refleksji o filmie historycznym, "Annales Universitatis Mariae Curie-Skłodowska. Sectio F, Historia" 2011, 56, 2, s. 87-113.

19 Idem, Historyczne filmy Andrzeja Wajdy, „Rocznik Instytutu Europy Środkowo-Wschodniej" 2015, 13, 1, s. 43-81. Książka habilitacyjna tego samego autora - Andrzej Wajda jako historyk - metodologiczne studium z historii wizualnej, Lublin 2016 - w sposób jednoznaczny (nawet jeżeli czasem spierałbym się o szczegóły) dowodzi, że można traktować filmowe reprezentacje przeszłości (także te, które określane są jako fabularne) jako odmianę refleksji historycznej.

20 M. Ferro, Historycy i kino, „Kino” 1989, 10, s. 26-27. Zob. także tegoż: Kino i historia, tłum. T. Falkowski, Warszawa 2011.

21 H. White, Historiografia i historiofotia, tłum. Ł. Zaremba, w: Film i historia. Antologia, red. I. Kurz, Warszawa 2008, s. 124. 
do opinii strony skarżącej (w przywołanym już fragmencie z pierwszego pisma procesowego jest wszak mowa o „reprezentatywności dla określonej rzeczywistości historycznej").

Problemem przedstawienia historii w filmie zajmował się także Robert A. Rosenstone. Podobnie jak White, zwraca on uwagę na fabularny (narrative) charakter każdej historii („Fakt, że film fabularny ze swej istoty opiera się na konfliktach między bohaterami [...] nie odróżnia go znacząco od większości dzieł historii pisanej" ${ }^{22}$ ). Rosenstone wskazuje kilka estetycznych technik historycznej reprezentacji (stosowanych zarówno w pisanej, jak i filmowej historii), spośród których warto wymienić dwa: kondensację i alternację. Kondensacja jest wedle badacza techniką przedstawiania relatywnie obszernego zdarzenia historycznego (na przykład: wojna, strajk, protest) za pomocą stosunkowo krótkich scen, które przedstawiają doświadczenie grupy społecznej (na zasadzie synekdochy - część zastępuje całość). Alternacja odnosi się do zmian, jakie wprowadza się do narracji (słownej czy filmowej) w odniesieniu do faktycznie udokumentowanych zdarzeń historycznych, by dokonać ogólniejszej konstatacji: brak wierności na poziomie dosłownym może wytworzyć prawdę dyskursywną. Pisze autor: „Musimy sobie uświadomić, że film zawsze będzie zawierać obrazy zarazem wymyślone i prawdziwe [...], prawdziwe $\mathrm{w}$ tym, że przekazują ogólne znaczenie przeszłości, która może być zweryfikowana, udokumentowana lub uargumentowana" ${ }^{23}$. Podkreślam - Rosenstone nie mówi tu o filmach dokumentalnych, ale o widowiskach, które określa się mianem „fabularnych”. Autor zaznacza zatem, że fikcjonalizacja (kreacja postaci czy zdarzeń, które nigdy nie istniały) może być wehikułem narracji historycznej oraz instrumentem docierania do prawdy o wydarzeniach minionych.

Oczywiście, sformułowanie „historyczny film fabularny” jest wieloznaczne i obejmuje szerokie spektrum dzieł. Możemy bowiem wyróżnić wśród nich, z jednej strony, fabuły z aspiracjami rekonstrukcji pewnych wydarzeń autentycznych, $\mathrm{w}$ tym filmy biograficzne (często zawierające rozbudowane partie fikcjonalne), z drugiej zaś - filmy ze zwiększoną „dawką" dramaturgicznych zdarzeń fikcjonalnych, których fabuła w części bądź w całości jest osadzona w przeszłości (np. można rozpoznać, że akcja rozgrywa się „gdzieś w średniowieczu”, ponieważ na ekranie

22 R.A. Rosenstone, Historia w obrazach/historia w słowach: rozważania nad możliwościa przedstawienia historii na taśmie filmowej, tłum. Ł. Zaremba, w: Film, s. 103. Zob. także: idem, Zobaczyć przeszłość, tłum. P. Witek w: Teoria wiedzy o przeszłości na tle wspótczesnej humanistyki. Antologia, red. E. Domańska, Poznań 2010, s. 319-350.

23 Idem, The Historical Film: Looking at the Past in a Postliterate Age, w: The Historical Film: History and Memory in Media, red. M. Landy, New Brunswick 2001, s. 60. 
pojawiają się rycerze $\mathrm{w}$ zbrojach). $\mathrm{W}$ tym ostatnim wypadku wrażenie „historyczności" wytwarzane jest przede wszystkim przez scenograficzno-kostiumograficzny design (w odniesieniu do takich filmów mówi się niekiedy o "filmie kostiumowym" czy - w anglojęzycznej nomenklaturze - o „period film”, czyli „film z epoki”), zaś wątki fikcjonalne zdecydowanie przeważają nad fabularyzacją historycznych faktów ogólnych lub wręcz nie wprowadzają tych ostatnich. Niemniej, także w przypadku "filmów z tłem" przesłanki rzeczywistych wydarzeń spowinowacone z fikcją mogą dać obraz o dużej sugestii autentyzmu podejmowanego tematu, tak by ta - wymyślona przecież - wizja sprawiała wrażenie, że mówi w istocie o rzeczywistości materialnej. W praktyce mamy do czynienia z wieloma modelami pośrednimi, a najczęstszą formułą wykorzystywaną przez kino powstające $w$ warunkach przemysłowych jest fabularyzacja historycznych faktów ogólnych, której towarzyszą rozbudowane wątki fikcjonalne (to przypadek przedmiotowego filmu). Tego typu realizacje posługują się logiką prawdopodobieństwa wobec faktycznego przebiegu wydarzeń; ukazują epizody, które - choć fikcjonalne - mogłyby się zdarzyć jako na swój sposób typowe dla prezentowanego okresu dziejów.

Inaczej mówiąc, dla sprecyzowania typu filmu historycznego jest określenie, czy (a jeśli tak - do jakiego stopnia) dany film odwołuje się do szczegółowych, konkretnych faktów minionych, a na ile do faktów ogólnych (poprzez np. wzmiankę o konkretnej wojnie lub wyniku militarnego starcia), czy też sceny ewokują jedynie tło jakiejś epoki poprzez rozmaite walory wizualne lub dźwiękowe (m.in. scenografię, kostiumy, muzykę). W przedmiotowym filmie takim faktem ogólnym jest II wojna światowa (a dokładniej: precyzyjnie wskazane lata 1941-1945), co dodatkowo akcentowane jest przez styl wizualny - stąd nie można serialu Nasze matki, nasi ojcowie uznać wyłącznie za film „kostiumowy”, jedynie „z tłem epoki".

Przedmiotowy film należy do dość rozpowszechnionego subgatunku "filmów historycznych z przewagą wątków fikcjonalnych, symulujących komunikat oparty na wydarzeniach autentycznych" - tj. film z fikcjonalnymi bohaterami, ale zarazem z licznymi odniesieniami do faktycznych wydarzeń z przeszłości. Ponad wszelką wątpliwość komunikat Nasze mat$k i$, nasi ojcowie nie może należeć do tej samej klasy filmów historycznych co Bękarty wojny (2009) Quentina Tarantino - jego film zawiera bowiem tzw. achronologizmy, tj. sceny niemożliwe z punktu widzenia wiedzy o historii (mianowicie: zabójstwo Hitlera). 


\section{KRYTERIA FIKCJONALIZACJI I AUTENTYFIKACJI}

Jak już zostało powiedziane, nie ma możliwości - ani w filmach dokumentalnych, ani fabularnych/aktorskich - by przedstawić stuprocentowo przeszłość "taka, jaka ona była". Dlaczego więc o jednych filmach (fabularnych aktorskich) mówi się, że przedstawiają historię lepiej, a o innych - że chybiają temu celowi? W grę wchodzą tu dwa kryteria: poziom fikcjonalizacji (na poziomie wydarzeń) oraz poziom autentyfikacji (głównie na poziomie stylu wizualno-dźwiękowego).

Dramaturgia (płaszczyzna wydarzeń) większości filmów o tematyce historycznej rozpięta jest pomiędzy dwiema strategiami: uhistorycznianiem fabuły fikcyjnej oraz fikcjonalizacją fabuły historycznej. W gruncie rzeczy różnorodność filmów historycznych zależy od miejsca, jakie zajmują na tej skali - z silniejszym „uhistorycznieniem fabuły fikcyjnej” mielibyśmy do czynienia np. we wspomnianych już Bękartach wojny. Z kolei fikcjonalizacja fabuły historycznej to domena wielu filmów biograficznych czy rekonstrukcji. Przedmiotowy film zajmowałby środkowe miejsce tej skali - przy czym zadziwiające i zastanawiające jest, że nie zawiera on planszy z napisem: „Wszystkie postaci i wydarzenia przedstawione na filmie są fikcyjne, a ich podobieństwo do prawdziwych postaci i zdarzeń jest przypadkowe" (lub podobnej). Producenci filmowi zazwyczaj chętnie umieszczają taką klauzulę, zwłaszcza w wypadku filmów nawiązujących do wydarzeń z niedalekiej przeszłości (właśnie po to, by w dodatkowy sposób zabezpieczyć się przez procesami). Powiedziałbym wręcz, że widzowie mogą oczekiwać tego rodzaju komunikatu - a jego brak traktować jako sygnał, że "coś z tego, co pokazane, wydarzyło się naprawdę".

Dla oceny charakteru filmu historycznego (czy raczej: dla precyzyjniejszego określenia jego subgatunku) fundamentalnie istotne są kwestie estetyczne. Najbardziej rozpowszechniana formuła widowiska filmowego posługuje się stylem klasycznym (określanym także jako zerowy lub przezroczysty), którego celem jest takie budowanie warstwy wizualnej i dźwiękowej, by „znaturalizować” wykreowane wydarzenia i doprowadzić do tzw. odbiorczej immersji, także poprzez usunięcie wszystkich elementów mogących przypomnieć widzowi, że ogląda "tylko" film. W konsekwencji, ewokowane jest wrażenie realności, które ma konsekwencje szczególnego rodzaju właśnie w odniesieniu do filmów historycznych - ukazuje bowiem historię w taki sposób, jakby prezentowane wydarzenia faktycznie się wydarzyły (tę kategorię filmów Rosenstone określa jako history as drama). Twórcy filmowi wiedzą że to nie jedyny sposób prowadzenia narracji filmowej-sztuka filmowa dysponuje szeroką gamą chwytów wykraczających poza dominujące konwencje przedstawieniowe, a zarazem 
przypominających widzowi, że to, co ogląda, to kulturowo wytwarzany konstrukt (typ history as experiment Rosenstone'a ${ }^{24}$ ).

Te - oczywiste dla każdego filmoznawcy - ustalenia nie są bez znaczenia dla omawianej sprawy procesowej. Serial Nasze matki, nasi ojcowie należy bowiem z pewnością do kategorii history as drama - jest bowiem bardzo sprawnie zrealizowaną produkcją głównego nurtu i nie zawiera „udziwnień" stylistycznych, które pozwoliłyby go określić formułą history as experiment. Strona reprezentująca pozwanych uważa tymczasem, że sam tylko fakt, że mamy do czynienia $\mathrm{z}$ aktorskim filmem fabularnym, niejako zwalnia go z odpowiedzialności od dywagacji na temat sposobu prowadzenia narracji historycznej. Natomiast w świetle teorii trzeba powiedzieć, że gdyby dla ukazania fabuły zastosowano inny styl - taki, którego elementy służyłyby utrzymaniu dystansu widza i wzmocnieniu postawy krytycznej - autorzy podkreśliliby wykreowany charakter komunikatu.

Elementem autentyfikującym jest oczywiście także wykorzystanie materiałów archiwalnych. W serialu Nasze matki, nasi ojcowie wykorzystano kilka czarno-białych sekwencji sprawiających wrażenie, jakby pochodziły z archiwalnych kronik (zdjęć niezainscenizowanych i niewytworzonych na potrzeby tej konkretnie miniserii). Piszę „sprawiających wrażenie" (wynikające m.in. z faktury i ziarna obrazu), bowiem widzowi pozbawionemu dostępu do materiałów producenta trudno jest zidentyfikować źródła pochodzenia konkretnych ujęć wchodzących w skład tych scen. Co więcej - jak zauważa Przylipiak - „film fabularny może podrobić wszystkie tekstualne cechy filmu dokumentalnego" ${ }^{\prime 25}$. W świetle tej argumentacji autentyczny (archiwalny, dokumentalny) charakter tych materiałów jest mniej ważny niż sama ich obecność i wrażenie, które wywołują (byłoby najpewniej bardzo podobne wówczas, gdyby charakter dokumentalny był imitowany za pomocą określonych środków stylistycznych: niestabilną kamerę z ręki, czarno-białą barwą obrazu czy jego "gruboziarnistą" fakturą). Najistotniejszy jest bowiem fakt, że ujęcia te wprowadzają - do całej narracji, nie tylko do scen, w których się zawierają - sygnał: to, co jest pokazane w partiach zainscenizowanych jest zbieżne z faktyczną notacją dokumentalną; ergo: rejestracje "archiwalne" są elementem autentyfikującym cały przekaz, i vice versa: partie barwne moga być odczytane jako dopełnienie rejestracji (potencjalnie) archiwalnych ${ }^{26}$.

\footnotetext{
24 R.A. Rosenstone, The Historical, s. 52-53. Zob. także: idem, Historia, s. 111.

25 M. Przylipiak, op. cit., s 27.

26 Materiałów - jak sądzę - archiwalnych jest w serialu dość dużo; zwraca także uwage stosunkowo długi czas trwania (czas ekranowy) budowanych przez nie scen. Przykładowo,
} 
Serial Nasze matki, nasi ojcowie zawiera także elementy autentyfikujące inne niż fragmenty "archiwalne”. W części III pojawia się (ok. $71 \mathrm{~min}$ 10 sek.) nagranie audio z BBC (lub nagranie imitujące takowe), a także (ok. 74 min 30 sek.) rekwizyt - gazeta z epoki (lub wykonana tak, by ją imitować). Podkreślam tu alternatywę "lub”, ponieważ widz nie ma w zasadzie żadnej możliwości stwierdzenia, czy materiał znakowany jako archiwalny bądź dokumentalny faktycznie ma taki charakter; przekonanie o takim właśnie statusie ontycznym sekwencji odróżniających się stylem od sekwencji jawnie aktorskich trzeba uznać za "domyślny" tryb odbioru (zwłaszcza gdy w napisach początkowych lub końcowych nie pojawia się formuła „wszystkie wydarzenia są fikcyjne”).

Nie tylko kwestie stylistyczne decydują o stopniu autentyfikacji materiału w filmie historycznym. Nie bez znaczenia jest także kontekstowa „otulina" (napisy początkowe i końcowe, materiały promocyjne, wywiady etc). Jeśli film w jakikolwiek sposób (poprzez treść lub poprzez kontekst) zostaje odczytany jako historyczny, wówczas naturalną procedurą odbiorczą (tak potoczna, jak i akademicką) jest ",analiza faktograficzna”, tj. ustalenie, czy przedstawia on wydarzenia prawdopodobne historycznie. Dowodem na to, że "analiza faktograficzna” stanowi typ lektury uruchamiany przy okazji filmów historycznych (także aktorskich filmów fikcjonalnych „z tłem epoki”) jest ich recepcja potoczna - na przykład komentarze internetowe (przez socjologów traktowane jako źródło w badaniach dyskursu publicznego). Niestety (była już o tym mowa) duża ich część krąży zazwyczaj wokół pytania: „czy tak było, czy tak nie było w rzeczywistości" (lub przysłowiowego już wśród filmoznawców pytania, kierowanego z lekkim uśmiechem pod adresem tej części historyków, którzy nie znają realiów produkcji filmowej: czy guziki wszyte w kostiumowe mundury to faktycznie ten sam "model i rozmiar", którym posługiwała się dana formacja militarna).

Autentyfikować przekaz mogą także elementy niediegetyczne (tj. ulokowane poza światem przedstawionym filmu). W miniserii Nasze matki, nasi ojcowie taką funkcje pełnią niewątpliwie nazwiska pięciu konsultantów historycznych (trzech z tytułami profesorskimi!), umieszczane w filmie na końcu każdego odcinka. „Stanowiska ekspertów z zakresu historii" zawiera także tzw. press-book serialu ${ }^{27}$ (przygotowywana przez producenta - lub dystrybutora, na podstawie materiałów dostarczonych

w odcinku III (8.30-9.00) mamy scenę trwającą 30 sekund (w przybliżeniu), złożoną aż z 14 ujęć.

27 Statements historischer Fachberater, w: „Unsere Mütter, unsere Väter”. Dreiteiliger Fernsehfilm, wyd. ZDF-Pressestelle, Mainz 2013, s. 25-26, (krótkie laudacje na cześć filmu przedstawili profesorowie: Rolf-Dieter Müller, Sönke Neitzel oraz Julius H. Schoeps). 
przez producenta - broszura informacyjno-reklamowa). W tym samym opracowaniu zamieszczono także wypowiedź producenta, Nico Hofmanna, który mówi o serialu, że to jego „najbardziej osobista produkcja, ukoronowanie wieloletniego pragnienia, by opowiedzieć przeżycia wojenne moich rodziców tak dokładnie, jak to możliwe" 28 .

\section{INTENCJONALNOŚĆ I ADRESAT DZIEŁA FILMOWEGO}

W dokumentacji procesowej sporo miejsca poświęcono intencji twórców filmu - co zrozumiałe o tyle, że określenie celowości czynu jest ważną przesłanką wpływającą na jego prawną klasyfikację. W niniejszym artykule nie podejmuję tego aspektu, chciałbym natomiast podkreślić, że $\mathrm{w}$ świetle teorii filmu zasadniczym argumentem na intencjonalność dzieła lub jego poszczególnych elementów jest sam film, tj. jego ostateczna wersja montażowa; $t z w$. parateksty (np. materiały promocyjne czy wypowiedzi twórców) mogą pełnić w tym zakresie rolę pomocniczą. Wynika to ze specyfiki toku produkcji filmowej, która w systemie profesjonalnym dzielona jest na kilka etapów: preprodukcyjny (w tym m.in: scenariusz, przygotowywanie na jego bazie dokumentów niezbędnych do zdjęć: scenopisu i tzw. kalendarzówki, wybór obsady, dekoracji i kostiumów), zdjęciowy (w tym: duble) i postprodukcyjny (montaż obrazu i dźwięku, kopia wzorcowa). Każdy z tych etapów podlega drobiazgowej kontroli ze strony szefów poszczególnych pionów, stąd też przyjmuje się, że skoro wykonano tzw. kopię wzorcową filmu (przeznaczoną do rozpowszechnienia), znaczy to, że wszystkie jego elementy zostały celowo i świadomie ukształtowane. Stąd w profesjonalnej produkcji filmowej nie można mówić o „przypadkowym” ukształtowaniu jakiegoś elementu składowego dzieła filmowego - z wyjątkiem ewidentnych błędów, takich jak obecność nieprzewidzianego obiektu $\mathrm{w}$ polu kamery czy usterek $\mathrm{w}$ tzw. ciągłości (anegdotyczny „zawiązany krawat w scenie $X$ oraz rozwiązany krawat w scenie $X+1$ "), niezauważonych na etapie zdjęciowym i przeoczonych w montażu (dziś z łatwością usterki takie koryguje się za pomocą efektów cyfrowych).

Powyższe wyjaśnienie jest istotne $\mathrm{z}$ uwagi na jeden $\mathrm{z}$ wątków sporu sądowego - dotyczącego opasek AK na ramionach polskich partyzantów. Otóż analiza filmu nie pozostawia wątpliwości, że w serialu mamy do czynienia wręcz z ostentacyjnym ( $\mathrm{z}$ uwagi na kadrowanie - ustawienie kamery i oświetlenie) podkreślaniem przynależności partyzantów do AK (np. 10 min 30 sek. oraz 53 min w odcinku III). Przyznaję, że byłem tym

\footnotetext{
28 N. Hofmann, Meine persönlichste Produktion, w: „Unsere, s. 11.
} 
zaskoczony - a konfuzja pogłębiła się po lekturze dokumentacji procesowej: skoro bowiem, jak utrzymują reprezentanci strony pozwanej, film miałby być adresowany do niemieckiego widza, po cóż było konfudować go jakoby niezrozumiałym dlań skrótem umieszczonym na opasce $\mathrm{z}$ barwami narodowymi Polski? Producenci filmowi $\mathrm{w}$ profesjonalnej produkcji zazwyczaj bowiem zważają na to, by w obrazie czy w ścieżce dźwiękowej nie pojawiły się odniesienia do konkretnych instytucji czy firm (z uwagi na ryzyko procesowe). Jeśli takowe odniesienia się pojawiaja dzieje się to zawsze po dokładnym namyśle (i decyzjach podejmowanych, jak wspomniałem, na różnych etapach powstawania filmu), najczęściej zaś z inicjatywy samych instytucji lub firm (product placement), z czym w omawianym wypadku nie możemy mieć do czynienia.

Strona reprezentująca pozwanych utrzymuje, że „przeciętny widz filmu nie włada językiem polskim, nie będąc tym samym w stanie skojarzyć skrótu $A K^{\prime \prime 29}$. Jest to domniemanie wsparte na niewłaściwych przesłankach - przede wszystkim z uwagi na to, że nie sposób określić, kim jest mityczny „przeciętny widz”. O ile można założyć, że prymarnym/ pierwotnym (w znaczeniu: pierwszego kraju dystrybucji) widzem filmu mógł być widz niemieckojęzyczny (w takim bowiem języku zgrano oryginalną ścieżkę dialogową), o tyle nie można z tego wysnuć wniosku, że film nie był przeznaczony dla widzów z innych krajów. Producent, zbywając prawa do dystrybucji na rzecz innego podmiotu, ma pełne prawo zastrzec brak zgody na rozpowszechnianie filmu w dowolnym kraju lub za pośrednictwem dowolnego medium; w przypadku przedmiotowego filmu tak się nie stało.

Przedstawiciele pozwanych twierdza, że „Polacy oraz partyzanci ukazani są $\mathrm{w}$ filmie wyłącznie $\mathrm{w}$ celu budowania dramaturgii; nie są oni natomiast tematem filmu" ${ }^{\prime 30}$. Tego rodzaju sformułowanie sugeruje, że pewne elementy filmu jedynie "budują dramaturgię", a inne - są faktycznie istotne dla jego wymowy. Tymczasem wszystkie ujęcia filmu mają potencjał znaczeniotwórczy. O tym, że sceny „z akowcami” nie są tylko motywem pobocznym (w kontekście przedmiotowego filmu można by rzec, że taką funkcję pełni wątek zdradzanej żony jednego z gestapowców) ani "tłem sytuacyjnym” (to można by powiedzieć np. o scenach w niemieckiej piwiarni, gdzie bohaterowie - w komplecie lub osobno - pojawiają się kilkakrotnie), lecz mogą być uznane za jeden z wątków wiodących, świadczy analiza wewnątrztekstowej dystrybucji części składowych fabuły - ilościowa (w III odcinku sceny „polskie” zajmują

29 Odpowiedź, s. 17.

30 Ibidem, s. 26. 
ok. 24 minut - z 94 minut czasu ekranowego), ale także jakościowa, ukierunkowana na interpretację konkretnych partii filmu.

W pozwie wskazano pięć konkretnych scen, które - zdaniem strony skarżącej - w szczególny sposób naruszają dobra osobiste powodów. W dalszej części tekstu poddam je analizie, odnosząc się także do konkretnych sformułowań z pism procesowych. Wcześniej jednak warto zastanowić się nad szerszym kontekstem sprawy.

\section{FABUŁY JAKO NOŚNIK TREŚCI NIENAWISTNYCH}

W świetle teorii kultury (i filmu) dzieła (także filmowe) posługujące się fikcją mogą być nośnikiem szowinistycznych stereotypów. Dowodem są tu oczywiście liczne komunikaty propagandowe - w tym filmy nakręcone w okresie III Rzeszy (takie jak słynny Żyd Süss), powszechnie w książkach i polsko-, i niemiecko-, i anglojęzycznych opisywane jako antysemickie ${ }^{31}$. Niemieckie filmoteki skrzętnie te filmy skrywaja, by - to zakaz ustawowy - „nie propagować nazizmu”. Jeżeli można propagować poprzez film (fabularny/aktorski) postawy antysemickie, to i antypolonizm, i wszelkie inne „anty": przykładowo, David Welch w swej książce o kinie III Rzeszy pisze wprost o filmach antypolskich (Heimkehr Ucicky'ego, Feinde Tourjanskyego), a także antyrosyjskich i antyangielskich ${ }^{32}$.

Trzeba $\mathrm{w}$ tym miejscu przypomnieć, że znaczenia $\mathrm{w}$ dziele filmowym odnoszące się np. do charakterystyki poszczególnych bohaterów wytwarzane są poprzez: ich wyglądy (kostiumy, rekwizyty itp.) oraz działania ( $w$ tym: wypowiadane dialogi) - na poziomie świata przedstawionego, a także chwyty narracyjne: ścieżkę dźwiękową lub/oraz montaż. W wypadku świata przedstawionego działania znaczeniotwórcze bliskie są doświadczeniom życia codziennego, ustalonym przez psychologię społeczną - przykładowo, jesteśmy bardziej skłonni ufać osobom uśmiechającym się i odczuwać niepokój, widząc osoby o zaciśniętych ustach oraz zmarszczonych brwiach. Oczywiście same wyglądy nie wystarczają do oceny człowieka w życiu codziennym - podobnie jak nie wystarczą do

31 W języku polskim: B. Drewniak, Teatr i film Trzeciej Rzeszy w systemie hitlerowskiej propagandy, Gdańsk 1972 (wyd. 2 uzup., Gdańsk 2011); T. Kłys, Od Mabusego do Goebbelsa: Weimarskie filmy Fritza Langa i kino niemieckie do roku 1945, Łódź 2013.

32 D. Welch, Propaganda and the German Cinema, 1933-1945, New York 1983 (i późniejsze wydania). Podkreślić warto, że United States Holocaust Memorial Museum w swojej bazie danych nazistowskich filmów propagandowych wykazuje tytuły tagowane jako „antisemitic”, „anti-British” i „anti-Polish”, zob. https://collections.ushmm.org/search/catalog/ [dostęp: 20 X 2018]. 
pełnej charakterystyki bohaterów (postacią negatywną może być przecież szarmancki, uśmiechający się człowiek, vide, ponownie, Bękarty wojny), bowiem efekty wyglądów mogą być zniesione albo potwierdzone/ wzmocnione przez działania bohaterów. W wypadku przedmiotowego filmu można zaryzykować opinię, że mamy do czynienia z tym drugim wariantem. „Powierzchniowość" polskich bohaterów (dokonany wybór aktorów o takim, a nie innym wyglądzie, kostiumy, sposób gry aktorskiej nadzorowanej przez reżysera) ukierunkowana jest na przedstawienie ich jako postaci niesympatycznych. Natomiast podejmowane przez nich działania "podbijają" negatywną charakterystykę, dopełniając ją o antysemityzm, który w świetle dialogów jest ich cechą zasadniczą.

Zdaniem pozwanych, trop taki pojawia się już w pierwszej scenie z żołnierzami AK [odcinek II, 1.21.40-1.23.59]. W powództwie pojawia się taki jej opis:

Alina, polska towarzyszka wędrówki Victora, wie, że bezpieczniej przedstawić Viktora partyzantom jako Niemca, niż przyznać prawdę, że jest on Żydem - od razu bowiem pytają o to i wydaje się to być dla nich kwestią najważniejszą $[\ldots]^{33}$.

Zgoła inaczej tę samą scenę opisuje przedstawiciel pozwanych:

Mężczyzna z brodą (dalej dowódca partyzantów) przesłuchuje Alinę na okoliczność jej pochodzenia. Następnie pyta Alinę o Viktora - czy jest Niemcem. Alina potwierdza. Potem zwraca się do Viktora, przybliżając się do niego i pociągając nosem, pyta po niemiecku Bist Du Jude? (Czy jesteś Żydem?). Na to pytanie odpowiada Alina, że nie. Następnie trwa krótka rozmowa na temat tego, skąd Alina wie, że Viktor nie jest Żydem. Atmosfera rozluźnia się na chwilę ${ }^{34}$.

Oba streszczenia posługują się nieco inną poetyką opisu - w piśmie strony skarżącej można dostrzec "psychologizowanie” bohatera (Alina „wie"), natomiast odpowiedź na pozew zdaje się bardziej sprawozdawcza, ponadto sugeruje „rozluźnienie” atmosfery. Zarazem jednak łagodzi ona faktyczną wymowę sceny - nader eufemistyczna peryfraza: „krótka rozmowa na temat tego, skąd Alina wie, że Viktor nie jest Żydem" odnosi się bowiem do dialogu, który w scenariuszu (i na ekranie) brzmi:

DOWÓDCA: Czemu jesteś tego taka pewna?

ALINA: Jak mówiłeś, pieprzę się z nim.

33 Pozew, s. 18.

34 Odpowiedź, s. 9. 
Szczególnie istotne dla sposobu prezentacji oddziału AK jest pierwsza scena odcinka III [0.2-0.6]. Powód widzi ją tak:

Rozkaz dowódcy: brać obraczki, złote zęby, zegarki jednoznacznie potwierdza rabunkowy charakter działalności tych ludzi. Złote zęby kojarzyć muszą się także z Holocaustem - rabowaniem martwych ofiar w obozach zagłady ${ }^{35}$.

W piśmie reprezentantów strony pozwanej czytamy natomiast:

[...] trzeba pamiętaćo realiach tamtych czasów, wartościowe przedmioty potrzebne były na wymianę (żywność, broń etc). Powszechne było przeszukiwanie zwłok, zbieranie amunicji i przedmiotów, które potem mogły się przydać $w$ innych okolicznościach, na przykład przy zdobywaniu pożywienia. Zresztą chronologicznie następna scena to właśnie kupowanie pożywienia od polskich chłopów. Polecenie przez dowódcę sprawdzenia złotych zębów u zmarłych, faktycznie kojarzy się z wyrywaniem złotych zębów ofiarom w Oświęcimiu, w tej jednak sytuacji należy to traktować jako formę odwetu na Niemcach ${ }^{36}$.

Przedstawiciele strony pozwanej potwierdzają że scena może ewokować kontekst obozowy, ale zarazem traktują tę scenę niczym „obrazek rodzajowy", pozostający w oderwaniu od innych partii filmu; tymczasem właśnie w nawiązaniu do nich motyw "złotych zębów” zyskuje faktyczne znaczenie (gdyby przyjąć, że faktycznie chodzi o jakąś ",formę odwetu”, nawet mało doświadczony scenarzysta wymyśliłby dziesiątki innych rozwiązań, równie skutecznie wyrażających tak zakładany cel - na przykład, podaję dowolne przykłady, zbezczeszczenie ciał zabitych przez oddanie na nich moczu lub obcięcie palców).

Żołnierze z AK nie są jedynymi Polakami w świecie fabularnym filmu. Mamy w serialu także scenę, w której członkowie oddziału kupują żywność od polskich chłopów [odcinek III: 0.9.03-0.10.44]. Powód pisze:

Polscy chłopi sprzedają żywność partyzantom (co było w rzeczywistości historycznej karane śmiercią) i są gotowi przekazywać żywność żołnierzom AK, ale pod warunkiem, że w oddziale partyzanckim nie ma i nie będzie Żydów. Jeden z gospodarzy pyta dowódcę: $A$ sa $u$ was Żydzi? - gdyż warunkiem wydania żywności jest brak obecności Żydów. Po zapewnieniu dowódcy, że Żydów nie ma (gdyż dowódca poznałby ich po smrodzie), gospodarz decyduje się sprzedać żywność,

35 Pozew, s. 19.

36 Odpowiedź, s. 14. 
zaznaczając: I żadnych Żydów, na co jeden z partyzantów odpowiada: Żydów potopimy jak koty ${ }^{37}$.

Tym razem to reprezentanci strony pozwanej próbują „psychologizować" zachowania członków oddziału. Sugerują mianowicie:

Nie ma wątpliwości, że wymiana zdań w stodole ma miejscami wydźwięk antysemicki. Jednak w pozwie scena ta została przeinterpretowana. Partyzanci zaprzeczaja, jakoby w ich oddziale byli Żydzi dlatego, że jest to konieczne w tej sytuacji, chłopi bowiem faktycznie dopytują się o obecność Żydów w kontekście podjęcia decyzji o sprzedaży jedzenia bądź nie. Partyzantom niewątpliwie jedzenie jest potrzebne. Zachowanie dowódcy w odpowiedzi na pytanie chłopów jest przerysowane, wręcz teatralne, dowódca odgrywa scenę poszukiwania Żydów, łącznie ze znaczącym, także teatralnym złapaniem się za nos i pociągnięciem, przy równoczesnym stwierdzeniu, że Żydów poznałby po smrodzie. W kontekście antysemickiego nastawienia chłopów takie zachowanie wydaje się konieczne, aby zdobyć ich zaufanie. Także odpowiedź partyzanta Stanisławskiego: Żydów potopimy jak koty jest wymuszona sytuacją i służy temu samemu, to jest podkreśleniu na potrzeby dobitego targu o żywność, że sprawa Żydów traktowana jest poważnie ${ }^{38}$.

Argumentacja o „teatralnym zachowaniu” byłaby logiczna tylko wtedy, gdyby zapomnieć o wspomnianej już scenie - poznania Viktora - w której już wcześniej bohaterowie oznakowani jako partyzanci AK ukazali swą niechęć do Żydów. Reprezentanci pozwanych wyraźnie rozróżniają przy tym zachowanie dowódcy (Jerzego) i jednego z partyzantów (Stanisławskiego). Istotnie, w serialu mamy do czynienia z pewnym zróżnicowaniem postaw między Jerzym a Stanisławskim - ale ponad wszelką wątpliwość obaj bohaterowie są przedstawieni jako antysemici (choć „w różnym natężeniu”).

Spór tyczy jednak także tego, czy taka charakterystyka odnosić się może do pozostałych bohaterów zaliczanych do kategorii „polscy chłopi” oraz „partyzanci z AK”. Otóż można uznać, że obie grupy są przedstawione jako antysemickie - w wypadku partyzantów znaczenie to jest wytwarzane przez bierność innych członków oddziału, którzy są świadkami większości kwestii wypowiadanych przez wspomniane dwie postaci oraz ich zachowań: nie reaguja, nie protestuja, mamy tu do czynienia z milczącym przyzwoleniem oraz akceptacją tych słów i działań. Dla tej

37 Pozew, s. 19.

38 Odpowiedź, s. 15. 
interpretacji zasadnicze znaczenie ma scena z uwolnieniem Żydów w pociągu [odcinek III, 0.44-0.50], którą powód opisuje w następujący sposób:

Akowcy atakują niemiecki transport kolejowy, wybijają załogę - jest to kulminacyjna akcja ataku na pociąg wiozący Żydów. Sam atak wygląda na kompletnie nieprzygotowaną akcję, chaotyczna, jakby partyzanci nie wiedzieli, co pociąg wiezie (w rzeczywistości historycznej tego rodzaju ataki były starannie przygotowane). Gdy okazuje się, że w środku są ludzie w pasiakach (akowcy zaglądają do środka zaledwie na sześć sekund, włącznie z czasem odsunięcia i zasunięcia drzwi z powrotem), natychmiast zamykają wagon. Viktor zaniepokojony takim rozwojem sytuacji pyta: $A$ co z nimi? Jeden z partyzantów stwierdza: Większość z nich to Żydzi (czyli są też osoby np. narodowości polskiej), co AK-owcy poznali po twarzach (jak wynika ze sceny). [...] Partyzantów interesuje jedynie broń, nie ludzie w bydlęcych wagonach. Viktor jednak wypuszcza osoby z bydlęcych wagonów. Partyzanci zostawili owych Żydów w wagonach, na śmierć. Nie towarzyszy temu żadna refleksja, nawet sprawdzenie, czy to rzeczywiście Żydzi, nie ma cienia wahania - wygląda jakby robili to nie pierwszy raz; ich zachowanie jest całkowicie naturalne i pokazuje absolutną oczywistość działania (w rzeczywistości historycznej tego rodzaju sytuacja nie miała miejsca ${ }^{39}$.

Powód przykłada do tej sceny dużą wagę, powraca do niej bowiem $\mathrm{w}$ innym miejscu pisma:

Żydzi są pozostawieni na śmierć, zaś wypuszczenie ich przez Viktora jest traktowane jako największa zbrodnia, jakiej mógł dokonać żołnierz Armii Krajowej (Viktor). Co więcej, w wymianie zdań przy bydlęcych wagonach pada wielce znaczące zdanie: Większość z nich to Żydzi, a Żydzi sa tak samo parszywi jak komuniści albo Ruskie - mówi Stanisławski. Mają tak zdechnać? - pyta Viktor. Tak - z krzywym uśmiechem odpowiada mu Stanisławski ${ }^{40}$.

Zupełnie inaczej czyta tę scenę reprezentant pozwanych. Najpierw rozprawia się z opinią o "nieprzemyślanym ataku” - odwołując się nie do „rzeczywistości historycznej”, ale argumentów tekstualnych, przeoczonych najwyraźniej przez powoda (,Nie jest tak, że atak na pociąg nie był zaplanowaną akcją. Partyzanci przygotowują się do niego, mają zdjęcia"41). Następnie przechodzą do meritum: „Nadużyciem jest powie-

\footnotetext{
Pozew, s. 19.

Ibidem, s. 23.

41 Odpowiedź, s. 11.
} 
dzenie, że wypuszczanie przez Viktora ludzi z pociągu jest »traktowane jako największa zbrodnia«. Nikt z partyzantów nie skomentował tego faktu, nie zareagował, nie powstrzymał Viktora ani słowem, ani geste$\mathrm{m}^{\prime \prime 2}$. Kilka stron dalej pojawia się rozwinięcie tej obserwacji:

Nie można też wysnuć z tej sceny wniosku, że pozostawiając ludzi zamkniętych $w$ wagonach, partyzanci sprawiają wrażenie, jakby robili to nie pierwszy raz, jakoby ich zachowanie było całkowicie naturalne. Zamknięcie wagonu przez dowódcę po tym, jak zobaczył w nich więźniów, jest wyrazem jego dezorientacji. Z informacji zwiadowczych $\mathrm{w}$ pociaggu miała być broń, a nie więźniowie. Tym samym w przekonaniu dowódcy oddział stracił amunicję; naraził się na zaatakowanie pociągu przewożącego coś innego niż przewidywano. W tych okolicznościach angażowanie się $\mathrm{w}$ ratowanie więźniów z pociągu było jednoznaczne z narażeniem całego oddziału. Tymczasem akcja tego typu wymagała dla swojej skuteczności szybkości i konspiracji. Poza tym $\mathrm{w}$ realiach walki podjazdowej trudno wymagać od partyzantów, aby zajmowali się ratowaniem więźniów na taką skalę ${ }^{43}$.

W fabule filmu decyzja Viktora pociąga za sobą jego wykluczenie z oddziału. Sekwencję tę [Odcinek III, 0.50.08-0.54.47] zrealizowano w interesujący, powiedziałbym: westernowy sposób, który tak opisuje powód:

Po zdemaskowaniu Viktor oczekuje na decyzję dowódcy. Żołnierz Stanisławski mówi do dowódcy: Przecież to jest Żyd, co z tym Żydem? Dowódca popijając alkohol, stwierdza, że się tym zajmie. Dowódca wyprowadza Viktora, każde mu iść przed soba, co ma sugerować prowadzenie na egzekucje - rozstrzelanie. Scena ta jest odbierana jako scena zbliżającego się morderstwa. Po czym odzywa się: Przeczuwałem to od początku. Inni mówili: on nim jest, wyglada na takiego i tutaj śmieje się drwiąco: Tak, Viktor, teraz to wiem. Jesteś Niemcem i Żydem - ma wyraz twarzy jakby zdemaskował zbrodnię. [...] Ładuje pistolet i wydaje Viktorowi rozkaz: idź, widz przyjmuje perspektywę prowadzonego na egzekucję Viktora. W tej scenie następuje kulminacyjny moment napięcia, pistolet $\mathrm{w}$ rękach Jerzego jest już nabity, Viktor stoi bezbronny i odwrócony tyłem, aranżacja tej sceny nasuwa jednoznaczne skojarzenia, że za chwilę padnie strzał. I nagle surowa i obojętna twarz Jerzego rozluźnia się, jakby się rozmyślił. Stwierdza, że wojna nie potrwa już długo. Staraj się przeżyć, życzę szczęścia - rzucając mu pogardliwie na ziemię pistolet. Twarz Viktora wyraża zaskoczenie, co oznacza, że był jednak pewny, iż będzie rozstrzelany ${ }^{44}$. 
Strona reprezentująca pozwanych nieco inaczej streszcza tę scenę. Warto zwrócić uwagę, że w odróżnieniu od wcześniejszego opisu nie ma tu mowy o popijaniu alkoholu przez dowódcę, brak też uwag o mimice bohaterów:

Dowódca budzi Viktora, każe mu się ubierać i opuszczają piwnicę, wychodzą na zewnątrz, dowódca popycha Viktora w stronę lasu. Następnie zatrzymują się i dowódca informuje Viktora, że od początku to przeczuwał, a teraz już to wie, że Viktor jest Niemcem, ale też Żydem. Potem stwierdza, że Viktor był świetnym kompanem, ale on już nie może nic dla niego zrobić. Dowódca ładuje broń, a następnie każe Viktorowi odejść. Po chwili woła za nim: Viktor, wojna nie potrwa już długo, życzę ci szczęścia, żebyś ja przeżyt. Następnie rzuca w stronę Viktora pistolet i znika ${ }^{45}$.

Faktyczne różnice dotyczą jednak nie opisu zdarzeń, ale ich interpretacji. Strona reprezentująca pozwanych potwierdza, że scena przypomina egzekucję - lecz nadaje jej zgoła inny sens:

Oczywiście, aby utrzymać napięcie u widza scena prowadzona jest $w$ ten sposób, że widz spodziewa się egzekucji. Niemcy w tym filmie w ten sposób zabijają strzelając w tył głowy. Dowódca oddziału partyzantów jednak nie tylko nie zabija Viktora, ale jeszcze daje mu broń. Wypuszcza go zatem, uzbrajając go, tym samym narażając siebie. Kreacja sceny faktycznie przypomina egzekucję, niemniej w przeciwieństwie do innych scen z udziałem niemieckich żołnierzy, tutaj jednak do egzekucji nie dochodzi. Krytyka tej sceny w kontekście jej podobieństwa do egzekucji nie jest zatem uzasadniona. To właśnie dzięki takiemu jej ukształtowaniu polski partyzant został pokazany jako ratujący życie Żydowi ${ }^{46}$.

To jednak interpretacja ryzykowna w kontekście wcześniejszych zdarzeń fabularnych; gdyby było tak, jak w przytoczonym zdaniu, strona pozwana musiałaby skorygować opinię, iż antysemicko nastawiony jest jedynie Stanisławski (skoro Jerzy chce uratować życie Viktorowi, a zagraża mu tylko Stanisławski, podczas gdy inni członkowie grupy nie są nastawieni antysemicko - wówczas Jerzy powinien raczej „policzyć się" właśnie ze Stanisławskim, przy wsparciu innych członków grupy). W omawianej scenie dowódca decyduje się raczej wymierzyć „łagodniejszy wymiar kary" - kary! - czyli skazać Viktora na dalszą tułaczkę i niepewny los. Zresztą ta sama scena zawiera kwestię dialogową: Już

45 Odpowiedź, s. 10.

46 Ibidem, s. 16. 
za pierwszym razem miałem przeczucie. Wszyscy mówili: to Żyd, wyglada na Żyda (w org. „die andere haben gesagt..." - inni mówili...). Kwestia ta potwierdza antysemicką „obsesję" - nie tylko bohatera, ale także innych członków oddziału.

\section{MONTAŻ JAKO CZYNNIK ZNACZENIOTWÓRCZY}

Przy tym wszystkim trzeba pamiętać, że znaczenia dzieła filmowego nie są sumą znaczeń poszczególnych scen, ale ich koniunkcja, tj. sygnały płynące z jednej sceny są dopowiadane (wzmacniane lub osłabiane) przez inne. Szczególne znaczenie ma przy tym sąsiedztwo obrazów - zarówno poszczególnych ujęć ( $\mathrm{tzw}$. efekt Kuleszowa: znaczenie ujęcia A jest ustalane przez ujęcie $A+1$ ), ale także sąsiadujących ze sobą scen. $W$ tym kontekście chciałbym zwrócić uwagę na zastosowane w filmie szczególne zabiegi montażowe (na poziomie łączenia scen właśnie).

Pod koniec odcinka II omawianego miniserialu (w przebiegu $87 \mathrm{~min}$ 15 sek. - 87 min 25 sek.) pojawiają się ujęcia skatowanego Viktora - i dopiero w kolejnym odcinku widz dowie się (choć informacje na ten temat i tak będą niepełne), co dokładnie stało się z bohaterem. W odniesieniu do odcinka II traktowanego jako integralna całość (zamknięta napisami końcowymi - a trzeba pamiętać, że formuła miniserialu nie wyklucza tego, że widz obejrzy tylko jeden z odcinków), scena ta może być dla widza pewnego rodzaju zaskoczeniem. Z pozoru to klasyczny "cliffhanger" - ale tylko z pozoru, bowiem zasadą zawieszenia akcji z odcinka na odcinek jest pytanie: „co stanie się z bohaterem?”, podczas gdy tutaj mamy do czynienia także z elipsą (ukryciem części zdarzeń minionych). Wcześniejsza scena, w której pojawił się Viktor, kończy się bowiem (83 min 55 sek.) lekko "siłowym” wyprowadzeniem bohatera z ziemianki; w świetle tej wskazówki tekstualnej widz (wypełniający w odbiorczej świadomości luki fabularne) ma pełne prawo podejrzewać, że Viktor został skatowany przez "partyzantów z AK” (na przykład z uwagi na swoje żydowskie pochodzenie - a zatem okoliczność, którą bohater ukrywa). O tym, że przebieg zdarzeń mógł być inny (choć, to znamienne, nie można mieć tej pewności - widz nie otrzymuje bowiem informacji, czy krew na twarzy Viktora nie była prawdziwa), dowiemy się dopiero na początku kolejnego odcinka. Wrażenie, z jakim pozostawia widza zakończenie odcinka drugiego, jest wytwarzane przez scenę znajdującą się chwilę po wspomnianym wyprowadzeniu (przesłuchanie Grety przez Gestapo zakończone jej pobiciem: 84 min - 85 min 30 sek.); ten sam wzór montażowy pojawi się trzy minuty później ( 87 min 25 sek.): pobita przez gestapowca Greta tuż przez skatowanym Viktorem. 
O tym, że mamy do czynienia z celowym podkreśleniem wspólnoty losów (ich podobieństwa, nie równoległości czasowej) Viktora i Grety, świadczą analogiczne zabiegi w odcinku trzecim. W przebiegu $50 \mathrm{~min}$ - 50 min 35 sek. Viktor w ziemiance "partyzantów z AK” jest wyraźnie przerażony, a narracja podbija tę emocję przywołanymi już dialogami. Cały sens tej sceny wyczerpuje się w lęku bohatera przed antysemicko nastawionymi partyzantami z AK, w żaden inny sposób nie można jej scharakteryzować. A dosłownie chwilę później widzimy Gretę oczekującą na wykonanie wyroku w gestapowskim więzieniu. Fakt, że obie sceny ulokowane są obok siebie, buduje relację analogiczności - pomiędzy ofiarami (Viktor i Greta), ale także między oprawcami (AK i Gestapo).

Sam producent filmu mówił w wywiadzie dla „Polska. The Times”: „Krytyka z Polski jest dla mnie szczególnie bolesna, ale rozumiem ją. I skoro pan o to pyta, to gwarantuję panu, że sceny w Polsce zrobiłbym inaczej - po głosach debaty, które śledzę od tygodni [...] naprawdę tragiczne $\mathrm{w}$ tym wszystkim jest to - $\mathrm{i}$ od tego nie mogę uciec - że na poziomie scenariusza skupiłem się najbardziej na wątku Viktora i tego, jak Żydowi może się udać przeżyć za granicą. Naszym błędem było, że nie poradziliśmy się tu historyków z Polski, bo wówczas moglibyśmy wiele zmienić jeszcze w montażu - pięcioma, sześcioma ujęciami mogliśmy zmienić nawet najtrudniejsze sekwencje. Zaniedbaliśmy to, ponieważ od strony dramaturgicznej najbardziej interesowało nas, jak niemiecki Żyd może przeżyć w Polsce. A tak doszło do spiętrzenia scen o antysemickiej wymowie" 47 .

\section{$* * *$}

Dotychczasowe rozprawy w sprawie „kapitan Zbigniew Radłowski oraz Światowy Związek Armii Krajowej versus UFA Fiction Gmbh oraz telewizja ZDF" przyciągały spore zainteresowanie medialne i były intensywnie komentowane na forach internetowych. Można powiedzieć, że mamy do czynienia z polską odsłoną ideologicznej batalii, którą w Stanach Zjednoczonych określa się mianem culture of offence - kultury obrazy. Areną tej walki jest dziś najczęściej kultura wizualna, w tym: filmowa - charakterystyki odnoszące się do płci, rasy, klasy społecznej czy wieku bywają trudne do zaakceptowania przez jednostki lub grupy, dla których przymioty te są punktem ogniskującym indywidualną lub

47 A. Dworak, Nico Hofmann, producent "Nasze matki, nasi ojcowie”: Zraniłem Polaków, „Polska”, wydanie elektroniczne, 28.06.2013, http://www.polskatimes.pl/artykul/931581,nico-hofmann-producent-nasze-matki-nasi-ojcowie-zranilem-polakow-przykro-mi,2,id,t, sa.html [dostęp: 30 X 2018]. 
zbiorową tożsamość i które mogą w związku z tym artykułować swe niezadowolenie, także poprzez pozwy sądowe.

Kategoria filmów historycznych stanowi w mym przekonaniu przypadek szczególny - „gatunek dwojakiego rodzaju”, by użyć przywołanej już frazy Witka. Jeśli przyjmiemy, że aktorski film fabularny jest pełnoprawnym sposobem narracji historycznej, musimy z tego stanowiska wyciągnąć pełne konsekwencje dotyczące także możliwych wykroczeń (przez ekranową narrację) poza stan wiedzy historycznej. Mamy tu najczęściej (i w omawianym wypadku) do czynienia z komunikatem, którego treść jest ontologicznie fikcjonalna, lecz który zarazem zachęca do czytania jej w trybie faktualnym. Nie może on być uznany za li tylko odbiorcze "widzimisię", albowiem jest „programowany" przez sam tekst filmowy, który staje się tym bardziej "autentyczny”, im sprawniej posługuje się środkami wytwarzającymi wrażenie realności, i który zyskuje na wiarygodności, jeśli zawiera instytucjonalny „placet” pod postacią ekspertyz historyków lub relacji członków ekipy zaświadczających, że ich celem jest odwzorowanie autentycznych zdarzeń.

Twórcy tego rodzaju filmów powinni być świadomi, że ich dzieła będą czytane w trybie "tak właśnie było" (jeśli w grę wchodzi fabularyzacja wydarzeń autentycznych) lub „tak bywało” (gdy weźmiemy pod uwage kategorie reprezentatywności i prawdopodobieństwa). Jeśli twórca filmu historycznego nie chciałby narazić się na zarzut niezgodności z wiedzą o okresie, jaki przedstawia, może wybrać jedną z trzech strategii postępowania. Po pierwsze, może wprowadzić do świata przedstawionego jakiś istotny achronologizm lub element fantastyczny, który podważyłby wrażenie realności. Po drugie, efekt taki może osiągnąć przez zabiegi stylistyczne - zastosowanie chwytów, które przypominałyby widzowi, że „to jest tylko film". Po trzecie wreszcie, sposobem uniknięcia nieporozumień (najprostszym i najtańszym z ekonomicznego punktu widzenia) jest wprowadzenie do filmu napisu, który informowałby, że wszystkie wydarzenia są fikcyjne. W serialu Nasze matki, nasi ojcowie nie wykorzystano żadnej z tych możliwości. Odznacza się on zarazem stosunkowo wysokim poziomem autentyfikacji, wytwarzanym zarówno na płaszczyźnie obrazów profilmowych (scenografia, kostiumy), stylu wizualno-dźwiękowego (praca kamery i montaż), jak i poprzez cechy niediegetyczne (informacja o konsultacjach historycznych) oraz kontekstualne parateksty (informacje z press-booka).

Gdy zaś idzie o sceny z oddziałem Armii Krajowej, to niewątpliwie zostały one zrealizowane i zmontowane w taki sposób, by przedstawić tę formację jako ugrupowanie nastawione antysemicko. W konsekwencji, w serialu zaprezentowano taką oto wizję II wojny światowej, podczas której to polscy partyzanci z AK zatrzaskują zasuwy w pociągu wiozącym żydowskich więźniów do Auschwitz, tych ostatnich zaś uwalnia 
bohater, który sam siebie uznaje za Niemca. Sceny te pełnią istotną rolę znaczeniotwórczą której treść wyczerpuje się w stwierdzeniu: „niemieccy naziści mogli liczyć na pomoc AK w swych zbrodniczych działaniach podszytych antysemicką nienawiścią".

W werdykcie z 28 grudnia 2018 r. (ogłoszonym po pięciu latach od złożenia pozwu) sędzia Kamil Grzesik, który od początku procesu prowadził sprawę, uznał, że takie rozpoznanie dokonane przez biegłego można uznać za argument potwierdzający naruszenie dóbr osobistych powodów. W myśl postanowienia sądu pozwani mieli zapłacić 20 tys. zł zadośćuczynienia, a także zamieścić - w mediach polskich i niemieckich - przeprosiny, w których treści będzie stwierdzenie, że miniserial Nasze matki, nasi ojcowie zawiera w swej treści nieuprawnione sugestie dotyczące rzekomego współdziałania AK w przeprowadzeniu Holokaustu oraz reprezentowania postaw antysemickich przez wszystkich żołnierzy tej formacji. Pełnomocnik pozwanych zapowiedział apelację; wygląda więc na to, że story is not over.

\section{REFERENCES (BIBLIOGRAFIA)}

\section{Legal documents (Dokumenty prawne)}

Dokumenty procesowe z Sądu Okręgowego w Krakowie, Wydział I Cywilny (sygn. akt. I C 2007/13).

„Pozew o naruszenie dóbr osobistych, prawa do znaku, wraz z żądaniem złożenia przeprosin i zadośćuczynienia" z 18 listopada 2013 r., złożony przez Kancelarię Pasieka, Derlikowski i Partnerzy.

„Odpowiedź na pozew”, przygotowana przez Kancelarię Góralski i Góralska z 27 lutego 2015.

\section{Studies (Opracowania)}

Bikont A., "Nie trzeba było domu palić, tylko Żydów wyprowadzić i pozabijać". Postscriptum do tekstu Jerzego Mazurka i Aliny Skibińskiej "Barwy Białe” w drodze na pomoc walczacej Warszawie: zbrodnie AK na Żydach, „Zagłada Żydów. Studia i Materiały” 2001, 7.

Drewniak B., Teatr i film Trzeciej Rzeszy w systemie hitlerowskiej propagandy, Gdańsk 1972 (wyd. 2 uzup., Gdańsk 2011).

Ferro M., Historycy i kino, „Kino” 1989, 10.

Ferro M., Kino i historia, tłum. T. Falkowski, Warszawa 2011.

Hendrykowski M., Stownik terminów filmowych, Poznań 1994.

Hofmann N., Meine persönlichste Produktion, w: "Unsere Mütter, unsere Väter". Dreiteiliger Fernsehfilm, wyd. ZDF-Pressestelle, Mainz 2013.

Kłys T., Od Mabusego do Goebbelsa: Weimarskie filmy Fritza Langa i kino niemieckie do roku 1945, Łódź 2013.

Kosińska-Krippner B., Parodystyczna natura przywłaszczania kodów i konwencji faktualnych w mock-dokumentach, „Kwartalnik Filmowy” 2006, 56.

Mazurek J., Skibińska A., "Barwy Białe” w drodze na pomoc walczacej Warszawie. Zbrodnie AK na Żydach, "Zagłada Żydów. Studia i Materiały” 2001, 7. 
Ogonowska A., «Mock-documentary» $i$ «faction genre»: wyzwanie dla kina dokumentalnego i paratekstualne gry $z$ widzem, w: Kino po kinie. Film w kulturze uczestnictwa, red. A. Gwóźdź, Warszawa 2010.

Przylipiak M., Poetyka filmu dokumentalnego, Gdańsk-Słupsk 2004.

Rosenstone R.A., Historia w obrazach/historia w stowach: rozważania nad możliwościa przedstawienia historii na taśmie filmowej, tłum. Ł. Zaremba, w: Film i historia. Antologia, red. I. Kurz, Warszawa 2008.

Rosenstone R.A., The Historical Film: Looking at the Past in a Postliterate Age, w: The Historical Film: History and Memory in Media, red. M. Landy, New Brunswick 2001.

Rosenstone R.A., Zobaczyć przeszłość, tłum. P. Witek w: Teoria wiedzy o przeszłości na tle wspótczesnej humanistyki. Antologia, red. E. Domańska, Poznań 2010.

Saryusz-Wolska M., Piorun C., Verpasste Debatte. "Unsere Mütter, unsere Väter” in Deutschland und Polens, "Osteuropa" 2014, 64, 11/12.

Skibińska A., "Dostał 10 lat, ale za co?". Analiza motywacji sprawców zbrodni na Żydach na wsi kieleckiej w latach 1942-1944, w: Zarys krajobrazu. Wieś polska wobec zagłady Żydów 1942-1945, red. B. Engelking, J. Grabowski, Warszawa 2011.

Statements historischer Fachberater, w: „Unsere Mütter, unsere Väter”. Dreiteiliger Fernsehfilm, wyd. ZDF-Pressestelle, Mainz 2013.

Welch D., Propaganda and the German Cinema, 1933-1945, New York 1983 (i późniejsze wydania).

White H., Historiografia i historiofotia, tłum. Ł. Zaremba, w: Film i historia. Antologia, red. I. Kurz, Warszawa 2008.

Witek P., Andrzej Wajda jako historyk - metodologiczne studium z historii wizualnej, Lublin 2016.

Witek P., Film historyczny jako "gatunek dwojakiego rodzaju". Kilka uwag metodologicznych $o$ "(nie)użyteczności" teorii genologicznej w refleksji o filmie historycznym, "Annales Universitatis Mariae Curie-Skłodowska. Sectio F, Historia" 2011, 56, 2.

Witek P., Historyczne filmy Andrzeja Wajdy, „Rocznik Instytutu Europy Środkowo-Wschodniej" 2015, 13, 1.

\section{Websites (Strony internetowe)}

Weis M., Nico Hofmanns Weltkriegsfilm verfehlt den Tagessieg, http://www.quotenmeter. de/n/62693 [dostęp: 20 X 2018].

Dworak A., Nico Hofmann, producent "Nasze matki, nasi ojcowie”: Zraniłem Polaków, „Polska”, wydanie elektroniczne, 28.06.2013, http://www.polskatimes.pl/artykul/931581,nico-hofmann-producent-nasze-matki-nasi-ojcowie-zranilem-polakow-przykro-mi,2,id,t ,sa.html [dostęp: 30 X 2018].

United States Holocaust Memorial Museum, https://collections.ushmm.org/search/catalog/ [dostęp: 20 X 2018].

\section{NOTA O AUTORZE}

Konrad Klejsa - dr hab., profesor w Katedrze Filmu i Mediów Audiowizualnych Uniwersytetu Łódzkiego. Ostatnie publikacje książkowe: Pamięć lat nazizmu w kinie niemieckim 1946-1965 (Łódź 2015); prace redakcyjne: Polska i Niemcy - filmowe granice i sąsiedztwa (Wrocław 2012); Badanie widowni filmowej. Antologia przekładów (wspólnie z M. Saryusz-Wolska, Warszawa 2014); Wokót zagadnień dystrybucji filmowej (wspólnie z M. Adamczak, Łódź 2015). Członek Rady Doskonałości Naukowej w kadencji 2020-2023. 